\title{
Occurrence of genes of putative fibrinogen binding proteins and hemolysins, as well as of their phenotypic correlates in isolates of S. lugdunensis of different origins
}

Florian Szabados", Yasmina Nowotny, Lennart Marlinghaus, Miriam Korte, Sandra Neumann, Martin Kaase and Sören G Gatermann

\begin{abstract}
Background: Staphylococcus lugdunensis is an important human pathogen that causes potentially fatal endocarditis, osteomyelitis and skin and soft tissue infections similar to diseases caused by Staphylococcus aureus. Nevertheless, in contrast to $S$. aureus, data on pathogenicity factors of S. lugdunensis is scarce. Two adhesins, a fibrinogen and a von Willebrand factor binding protein, and a S. lugdunensis synergistic hemolysin (SLUSH) have been previously described. Moreover, the newly sequenced genome of S. lugdunensis revealed genes of other putative fibrinogen binding adhesins and hemolysins. The aim of this study was to gain more insight into the occurrence of genes likely coding for fibrinogen binding adhesins and hemolysins using clinical strains of S. lugdunensis.
\end{abstract}

Findings: Most of the putative adhesin genes and hemolysin genes investigated in this study were highly prevalent, except for the SLUSH gene cluster. In contrast to previous reports, binding to fibrinogen was detected in $29.3 \%$ of the S. lugdunensis strains. In most strains, hemolysis on blood agar plates was weak after $24 \mathrm{~h}$ and distinct after $48 \mathrm{~h}$ of incubation. The fibrinogen binding and hemolysis phenotypes were also independent of the type of clinical specimen, from which the isolates were obtained.

Conclusion: In this study we described a pyrrolidonyl arylamidase negative S. lugdunensis isolate. Our data indicate that a matrix-assisted laser desorption ionisation time-of-flight MS-based identification of S. lugdunensis or speciesspecific PCR's should be performed in favour of pyrrolidonyl arylamidase testing. In contrast to the high occurrence of putative fibrinogen binding protein genes, $29.3 \%$ of the S. lugdunensis strains bound to fibrinogen. Putative hemolysin genes were also prevalent in most of the $S$. lugdunensis strains, irrespective of their hemolysis activity on Columbia blood agar plates. Similar to a previous report, hemolysis after $48 \mathrm{~h}$ of incubation is also indicative for $\mathrm{S}$. lugdunensis. The SLUSH gene cluster was detected in an estimated 50\% of the strains, indicating that this locus is different or non-prevalent in many strains.

\section{Background}

Staphylococcus lugdunensis is an important human pathogen that causes potentially fatal endocarditis, osteomyelitis and skin and soft tissue infections (SSTI) similar to diseases caused by $S$. aureus [1-5]. Fibrinogen and fibronectin binding adhesins have been discussed as

\footnotetext{
* Correspondence: Florian.Szabados@rub.de

Institute for Hygiene and Microbiology, Dept. for Medical Microbiology, University Bochum Universitätsstraße 150, Bochum, Germany
}

a pathogenicity factor of $S$. aureus [6,7]. In S. lugdunensis, two adhesins, the fibrinogen binding protein ( $\mathrm{Fbl}$ ) [8-10] and the von Willebrand factor binding protein [11] have been described. A hemolysin, the S. lugdunensis synergistic hemolysin (SLUSH), has also been described [12,13]. The newly sequenced genome [14] of S. lugdunensis has revealed an additional gene (SLGD_01696) that has been annotated as a putative fibrinogen/fibronectin binding adhesin [15]. Nevertheless, data on the prevalence of S. lugdunensis adhesins

\section{() Biomed Central}


and hemolysins, in contrast to S. aureus, is scarce. We therefore designed primers (Table 1) to characterize the occurrence of genes coding for putative fibrinogen binding proteins and supposed hemolysins.

\section{Methods \\ Bacteria}

Fifty-eight clinical strains of S. lugdunensis representing single patient isolates collected non-consecutively between 2003 and 2008 were included in this study (Table 2). This collection represents both urban and rural settings from the Bochum area, as well as a variety of community and institutional facilities. S. lugdunenis was preliminary identified by typical characteristics, such as odor, and the GPI-card by the Vitek-2 automated identification system (bioMérieux, Marcy l'Etoile, France). In addition, the strains were tested for the presence of ornithine decarboxylase (ODC), an enzyme that catalyzes the decarboxylation of ornithine to form putrescine. Retrospectively, the presence of the pyrrolidonyl arylamidase (PYR), which hydrolyzes L-pyrrolidonyl- $B$ naphtylamide to L-pyrrolidone and $\beta$-naphtylamide, was also tested. The S. lugdunensis type strain DSM 4804 was used as a positive control in both tests. The species diagnosis was confirmed using matrix-assisted laser desorption/ionization time-of-flight (MALDI-TOF) mass spectrometry (MS) [16] and amplification of the $\tan A$ gene, as previously described [17]. A single isolate was also confirmed by sequencing of the $\operatorname{sod} A$ gene, as previously described [18] Three strains of S. epidermidis (n $=2)$ and $S$. hominis $(\mathrm{n}=1)$ initially misidentified as $S$. lugdunensis were excluded from this study.
PCR

Strains were molecularly characterized with regard to genes coding for putative fibrinogen binding proteins, such as $f b l$, SLGD 1696 (FbpA), a von Willebrand factor binding protein gene $v w b l$, and genes coding for putative hemolysins [14]. The published sequences were used $[8,9]$ to design a primer pair for the detection of the $f b l$ gene (Table 1). The von Willebrand factor binding protein precursor gene $(\nu w b l)$ sequences (AY530288) [11] and SLGD_02429 [14] were used to design a primer pair for the detection of the $v w b l$ gene. The annotated putative fibrinogen/fibronectin binding protein (SLGD_01696) gene sequence [14] was used to design primers to amplify this gene (Table 1). The SLUSH gene sequence (U73444.1) [12], the annotated putative beta-hemolysin (SLGD_00006) gene sequence [14] and the annotated putative hemolysin III (SLGD_00847) gene sequence [14] were used to design primers for the detection of the beta-hemolysin and hemolysin III genes (Table 1). Genomic DNA of S. lugdunensis was extracted using the QIAamp DNA Mini Kit (Quiagen, Hilden, Germany) suspending the bacteria in the recommended buffer and addition of $20 \mu \mathrm{g}$ lysostaphin at the lysis step. The master mix contains dNTP's (dATP, dCTP, dGTP, and dTTP), 2 units of pure Taq DNA polymerase and reaction buffer. The reaction contained also 12.5 pmoles of each primer, $5 \mu \mathrm{l}$ of 1:10 diluted template DNA, and water to $25 \mu \mathrm{l}$. All PCRs used an initial denaturation at $94^{\circ} \mathrm{C}$ for $5 \mathrm{~min}$, followed by 35 cycles of an annealing step at $55^{\circ} \mathrm{C}$ for $30 \mathrm{~s}$, an elongation step at $72^{\circ} \mathrm{C}$ for $60 \mathrm{~s}$ and denaturation step at $94^{\circ} \mathrm{C}$ for $30 \mathrm{~s}$.

Table 1 Primers used for detection

\begin{tabular}{|c|c|c|c|c|}
\hline Gene/locus-tag & Name & Sequence $5^{\prime} 3^{\prime}$ & Size (bp) & Primer \\
\hline \multirow[t]{2}{*}{$f b l$} & fbl_check_F & CGTATTATCCCAAGTAGCAACC & 404 & This study \\
\hline & fbl_check_R & CTTCATCGATTGTCCCAGTAGC & & \\
\hline \multirow[t]{2}{*}{ SLGD_01696 } & FbpA_F & GAGATTACTGGACAACAAACG & 558 & This study \\
\hline & FbpA_R & GTATTGTGACGTCGTTTCCTG & & \\
\hline \multirow[t]{2}{*}{ SLGD_00006 } & betahemolysin_F & TGGTCAAGGTACAGAAGGTTGGCA & 449 & This study \\
\hline & betahemolysin_R & TATCCCAACTATACGCGTTGCCCT & & \\
\hline \multirow[t]{2}{*}{ SLGD_00847 } & hemolysinIII_F & TAATGCTGTITCGCACGGAGTTGC & 407 & This study \\
\hline & hemolysinlll_R & GACGCCTACCCATCCCATTACAA & & \\
\hline \multirow[t]{2}{*}{ SLUSH-cluster } & slush_donvito_F & TTTCGTCTTTGCACACACATTTCCA & 977 & This study \\
\hline & slush_donvito_R & ACAGCACAAAGCCTTAACTATCTCA & & \\
\hline SLGD_02429 & stlu_vwbl_F & TGGCGGGATGATITGGACGGG & 858 & This study \\
\hline$v w b l$ & stlu_vwbl_R & TCGCCTTCTTGCCCTGATGGT & & \\
\hline
\end{tabular}

The previously published fibrinogen binding protein gene $(f b l)$ sequences $[8,9]$, the von Willebrand factor binding protein precursor gene ( $v w b l)$ sequences (AY530288) [18] and SLGD_02429 [13], the putative fibrinogen/fibronectin binding protein (FbpA homologue SLGD_01696) gene sequence [13], the S. lugdunensis synergistic hemolysin (SLUSH) gene sequence (U73444.1) [11], the S. lugdunensis putative beta-hemolysin (SLGD_00006) gene sequence [11] and the S. lugdunensis putative hemolysin III (SLGD_00847) gene sequence [11] were used to design primer pairs (This study). 
Table 2 Occurrence of putative fibrinogen binding protein and hemolysin genes and their phenotypic correlates

\begin{tabular}{|c|c|c|c|c|c|c|c|c|c|c|c|c|c|c|c|}
\hline Strains & $\begin{array}{l}\text { Type of } \\
\text { culture }\end{array}$ & $\begin{array}{l}\text { Species } \\
\text { specific } \\
\tan A \text { gene }\end{array}$ & PYR & ODC & $\begin{array}{l}\text { Clumping } \\
\text { factor }\end{array}$ & $\begin{array}{l}\text { Binding to } \\
\text { solid-phase } \\
\text { fibrinogen }\end{array}$ & $\begin{array}{l}\text { Slidex } \\
\text { Staph } \\
\text { plus }\end{array}$ & $f b l$ & $\begin{array}{l}\text { SLGD_01696 } \\
\text { FbpA }\end{array}$ & $v w b l$ & $\begin{array}{l}\text { Hemolysis on } \\
\text { Columbia blood } \\
\text { agar after } 24 \mathrm{~h}\end{array}$ & $\begin{array}{l}\text { Hemolysis on } \\
\text { Columbia blood } \\
\text { agar after } 48 \mathrm{~h}\end{array}$ & $\begin{array}{l}\text { SLGD_00847 } \\
\text { hemolysin III }\end{array}$ & $\begin{array}{l}\text { SLGD_00006 } \\
\text { beta- } \\
\text { hemolysin }\end{array}$ & $\begin{array}{l}\text { SLUSH } \\
\text { gene } \\
\text { cluster }\end{array}$ \\
\hline Stlu 12 & $\begin{array}{l}\text { blood } \\
\text { culture }\end{array}$ & + & + & + & + & + & + & + & + & - & - & + & + & + & - \\
\hline Stlu 17 & $\begin{array}{l}\text { blood } \\
\text { culture }\end{array}$ & + & + & + & - & - & - & + & + & + & - & + & + & + & - \\
\hline Stlu 20 & $\begin{array}{l}\text { blood } \\
\text { culture }\end{array}$ & + & + & + & - & - & $(+)$ & + & + & + & + & ++ & + & + & - \\
\hline Stlu 21 & $\begin{array}{l}\text { blood } \\
\text { culture }\end{array}$ & + & + & + & + & +++ & + & + & + & + & - & + & + & + & + \\
\hline Stlu 22 & $\begin{array}{l}\text { blood } \\
\text { culture }\end{array}$ & + & + & + & - & - & - & + & + & + & - & + & + & + & + \\
\hline Stlu 25 & $\begin{array}{l}\text { blood } \\
\text { culture }\end{array}$ & + & + & + & - & - & - & + & + & + & - & + & + & + & + \\
\hline Stlu 27 & $\begin{array}{l}\text { blood } \\
\text { culture }\end{array}$ & + & + & + & + & + & + & + & + & + & - & + & + & + & + \\
\hline Stlu 28 & $\begin{array}{l}\text { blood } \\
\text { culture }\end{array}$ & + & + & + & - & - & - & + & + & + & - & - & + & + & + \\
\hline Stlu 30 & $\begin{array}{l}\text { blood } \\
\text { culture }\end{array}$ & + & + & + & - & - & - & + & + & + & - & + & + & + & + \\
\hline Stlu 32 & $\begin{array}{l}\text { blood } \\
\text { culture }\end{array}$ & + & + & + & + & + & + & + & + & + & - & + & + & + & + \\
\hline Stlu 33 & $\begin{array}{l}\text { blood } \\
\text { culture }\end{array}$ & + & + & + & - & - & - & + & + & + & - & + & + & + & + \\
\hline Stlu 34 & $\begin{array}{l}\text { blood } \\
\text { culture }\end{array}$ & + & $\pm^{*}$ & + & - & - & - & + & + & + & - & + & + & + & + \\
\hline Stlu 39 & $\begin{array}{l}\text { blood } \\
\text { culture }\end{array}$ & + & + & + & - & - & - & + & + & + & - & + & + & + & + \\
\hline Stlu 50 & $\begin{array}{l}\text { blood } \\
\text { culture }\end{array}$ & + & + & + & + & ++ & + & + & + & + & - & + & + & + & - \\
\hline Stlu 53 & $\begin{array}{l}\text { blood } \\
\text { culture }\end{array}$ & + & + & + & + & + & + & + & + & + & - & + & + & + & - \\
\hline Stlu 58 & $\begin{array}{l}\text { blood } \\
\text { culture }\end{array}$ & + & + & + & + & + & + & + & + & + & + & + & + & + & - \\
\hline Stlu 2 & $\begin{array}{l}\text { wound } \\
\text { swab }\end{array}$ & + & + & + & - & - & - & + & + & + & - & + & + & + & + \\
\hline Stlu 3 & $\begin{array}{l}\text { wound } \\
\text { swab }\end{array}$ & + & + & + & - & - & - & + & + & + & - & + & + & + & - \\
\hline Stlu 5 & $\begin{array}{l}\text { wound } \\
\text { swab }\end{array}$ & + & + & + & - & - & - & + & + & + & - & + & + & + & + \\
\hline
\end{tabular}


Table 2 Occurrence of putative fibrinogen binding protein and hemolysin genes and their phenotypic correlates (Continued)

\begin{tabular}{|c|c|c|c|c|c|c|c|c|c|c|c|c|c|c|c|}
\hline Stlu 6 & $\begin{array}{l}\text { wound } \\
\text { swab }\end{array}$ & + & + & + & + & +++ & + & + & + & + & - & + & + & + & - \\
\hline Stlu 7 & $\begin{array}{l}\text { wound } \\
\text { swab }\end{array}$ & + & - & + & + & + & + & + & + & + & - & + & + & + & - \\
\hline Stlu 8 & $\begin{array}{l}\text { wound } \\
\text { swab }\end{array}$ & + & + & + & + & +++ & + & + & + & + & - & + & + & - & - \\
\hline Stlu 10 & $\begin{array}{l}\text { wound } \\
\text { swab }\end{array}$ & + & + & + & - & - & - & + & + & + & - & + & + & + & - \\
\hline Stlu 11 & $\begin{array}{l}\text { wound } \\
\text { swab }\end{array}$ & + & + & + & - & - & - & + & + & + & - & + & + & + & - \\
\hline Stlu 13 & $\begin{array}{l}\text { wound } \\
\text { swab }\end{array}$ & + & + & + & + & + & $(+)$ & + & + & + & - & + & + & + & + \\
\hline Stlu 14 & $\begin{array}{l}\text { wound } \\
\text { swab }\end{array}$ & + & + & + & - & - & - & + & + & + & - & + & + & + & - \\
\hline Stlu 15 & $\begin{array}{l}\text { wound } \\
\text { swab }\end{array}$ & + & + & + & + & + & + & + & + & + & - & + & + & + & - \\
\hline Stlu 16 & $\begin{array}{l}\text { wound } \\
\text { swab }\end{array}$ & + & + & + & - & - & - & + & + & + & - & + & + & + & - \\
\hline Stlu 23 & $\begin{array}{l}\text { wound } \\
\text { swab }\end{array}$ & + & + & + & - & - & - & + & + & + & - & + & + & + & + \\
\hline Stlu 24 & $\begin{array}{l}\text { wound } \\
\text { swab }\end{array}$ & + & + & + & - & - & - & + & + & + & - & + & + & + & + \\
\hline Stlu 26 & $\begin{array}{l}\text { wound } \\
\text { swab }\end{array}$ & + & + & + & - & - & - & + & + & + & - & - & + & + & + \\
\hline Stlu 29 & $\begin{array}{l}\text { wound } \\
\text { swab }\end{array}$ & + & + & + & - & - & - & + & + & + & - & + & + & + & + \\
\hline Stlu 35 & $\begin{array}{l}\text { wound } \\
\text { swab }\end{array}$ & + & + & + & - & - & - & + & + & + & - & + & + & + & + \\
\hline Stlu 36 & $\begin{array}{l}\text { wound } \\
\text { swab }\end{array}$ & + & + & + & - & - & - & + & + & + & - & + & + & + & + \\
\hline Stlu 37 & $\begin{array}{l}\text { wound } \\
\text { swab }\end{array}$ & + & + & + & - & - & - & + & + & + & + & + & + & + & - \\
\hline Stlu 38 & $\begin{array}{l}\text { wound } \\
\text { swab }\end{array}$ & + & + & + & - & - & - & + & + & + & - & + & + & - & + \\
\hline Stlu 40 & $\begin{array}{l}\text { wound } \\
\text { swab }\end{array}$ & + & + & + & - & - & - & + & + & + & - & + & + & + & - \\
\hline Stlu 41 & $\begin{array}{l}\text { wound } \\
\text { swab }\end{array}$ & + & + & + & + & +++ & + & + & + & + & - & + & + & + & - \\
\hline Stlu 42 & $\begin{array}{l}\text { wound } \\
\text { swab }\end{array}$ & + & + & + & + & + & + & + & + & + & - & + & + & + & + \\
\hline Stlu 43 & $\begin{array}{l}\text { wound } \\
\text { swab }\end{array}$ & + & + & + & - & - & - & + & + & + & - & + & + & + & + \\
\hline
\end{tabular}


Table 2 Occurrence of putative fibrinogen binding protein and hemolysin genes and their phenotypic correlates (Continued)

\begin{tabular}{|c|c|c|c|c|c|c|c|c|c|c|c|c|c|c|}
\hline Stlu 44 & $\begin{array}{l}\text { wound } \\
\text { swab }\end{array}$ & + & + & + & - & - & - & $+\quad+$ & + & - & + & + & + & - \\
\hline Stlu 45 & $\begin{array}{l}\text { wound } \\
\text { swab }\end{array}$ & + & + & + & + & ++ & + & $+\quad+$ & + & - & + & + & + & + \\
\hline Stlu 49 & $\begin{array}{l}\text { wound } \\
\text { swab }\end{array}$ & + & + & + & - & - & - & $+\quad+$ & + & - & + & + & + & - \\
\hline Stlu 52 & $\begin{array}{l}\text { wound } \\
\text { swab }\end{array}$ & + & + & + & + & + & $(+)$ & $+\quad+$ & + & - & + & + & + & - \\
\hline Stlu 54 & $\begin{array}{l}\text { wound } \\
\text { swab }\end{array}$ & + & + & + & - & - & - & $+\quad+$ & + & - & + & + & + & - \\
\hline Stlu 55 & $\begin{array}{l}\text { wound } \\
\text { swab }\end{array}$ & + & + & + & - & - & - & $+\quad+$ & + & + & ++ & + & + & - \\
\hline Stlu 57 & $\begin{array}{l}\text { wound } \\
\text { swab }\end{array}$ & + & + & + & - & - & - & $+\quad+$ & + & - & + & + & + & - \\
\hline Stlu 59 & $\begin{array}{l}\text { wound } \\
\text { swab }\end{array}$ & + & + & + & - & - & - & $+\quad+$ & + & - & + & + & + & - \\
\hline Stlu 60 & $\begin{array}{l}\text { wound } \\
\text { swab }\end{array}$ & + & + & + & - & - & - & $+\quad+$ & + & - & + & + & + & + \\
\hline Stlu 61 & $\begin{array}{l}\text { wound } \\
\text { swab }\end{array}$ & + & + & + & - & - & - & $+\quad+$ & + & - & - & + & + & + \\
\hline Stlu 9 & cathether & + & + & + & - & - & - & $+\quad+$ & + & - & + & + & + & - \\
\hline Stlu 19 & cathether & + & + & + & - & - & - & ++ & + & + & ++ & + & + & + \\
\hline Stlu 1 & $\begin{array}{l}\text { knee } \\
\text { aspirate }\end{array}$ & + & + & + & + & + & - & $+\quad+$ & + & - & + & + & + & + \\
\hline Stlu 4 & $\begin{array}{l}\text { knee } \\
\text { aspirate }\end{array}$ & + & + & + & - & - & - & ++ & + & - & + & + & + & - \\
\hline Stlu 18 & $\begin{array}{l}\text { knee } \\
\text { aspirate }\end{array}$ & + & + & + & - & - & - & $+\quad+$ & + & - & + & + & + & - \\
\hline Stlu 31 & $\begin{array}{l}\text { knee } \\
\text { aspirate }\end{array}$ & + & $\pm^{*}$ & + & - & - & - & $+\quad+$ & + & - & + & + & + & + \\
\hline Stlu 51 & $\begin{array}{l}\text { knee } \\
\text { aspirate }\end{array}$ & + & + & + & - & - & - & $+\quad+$ & + & - & ++ & + & + & - \\
\hline Stlu 48 & $\begin{array}{l}\text { bone } \\
\text { aspirate }\end{array}$ & + & + & + & - & - & - & $+\quad+$ & + & - & + & + & + & - \\
\hline
\end{tabular}

Fifty-eight clinical strains of S. lugdunensis representing single patient isolates were used in this study. The strains were characterized with regard to putative fibrinogen binding and hemolysin genes and compared to their phenotypic correlates. Strains with a complete hemolysis were interpreted as positive (+). Strains producing no hemolysis (-) were compared to the negative control S. carnosus TM 300 . Strains with a strong hemolysis after $48 \mathrm{~h}$ similar to that of $S$. aureus Cowan I were interpreted as producing strong hemolysis $(++) ;+=$ positive; $-=$ negative; $(+)=$ weakly positive; $++=$ strongly positive; $\pm^{*}=$ test result indeterminate; pyrrolidonyl arylamidase (PYR); ornithine decarboxylase (ODC). 


\section{Bacterial adherence to solid-phase fibrinogen}

Binding of bacterial cells to immobilized fibrinogen was previously described [19]. Briefly, the strains were grown in $4 \mathrm{ml} \mathrm{LB}$-medium for $18 \mathrm{~h}$ at $37^{\circ} \mathrm{C}$ and $100 \mathrm{rpm}$. A 96-well microtiter plate was coated with $20 \mu \mathrm{g} / \mathrm{ml}$ of purified fibrinogen (plasminogen, von Willebrand factor and fibronectin depleted, Enzyme Research Laboratories, South Bend, USA) in PBS ( $\mathrm{NaCl} 137 \mathrm{mM}, \mathrm{KCl} 2.7 \mathrm{mM}$, $\mathrm{Na}_{2} \mathrm{HPO}_{4} 10 \mathrm{mM}, \mathrm{KH}_{2} \mathrm{PO}_{4} 1.76 \mathrm{mM}, \mathrm{pH}$ 7.4) for $18 \mathrm{~h}$ at $4^{\circ} \mathrm{C}$. After the solution had been discarded, bovine serum albumin $(2 \%, \mathrm{w} / \mathrm{v}$, in PBS) was added for $1 \mathrm{~h}$ at $37^{\circ} \mathrm{C}$. The plates were washed three times with PBS; then $100 \mu \mathrm{l}$ of a cell suspension (washed two times in PBS) of OD600 $=1.0$ was added and incubated at room temperature for $2 \mathrm{~h}$. The wells were washed three times with PBS and bound cells were fixed with $100 \mu \mathrm{l}$ formaldehyde $(25 \%, \mathrm{v} / \mathrm{v})$ for $30 \mathrm{~min}$ at room temperature. Adherent cells were washed with PBS twice, stained with crystal violet $(0.5 \%, \mathrm{v} / \mathrm{v})$ for $10 \mathrm{~min}$ at room temperature, then washed with PBS again, and dried at $37^{\circ} \mathrm{C}$. Absorbance was measured at $550 \mathrm{~nm}$ in an ELISA plate reader (Bio Kinetics Reader EL340, Bio-Tek Instruments). An $\mathrm{OD}_{550}$ value of 0 to 0.06 was interpreted as negative, 0.07 to 0.15 as intermediately positive $(+), 0.15$ to 0.3 as positive $(++)$, and $>0.3$ as strongly positive $(++$ + ). The S. aureus Newman (ATCC 25904) was used as a positive control and tested strongly positive $(+++)$. A sample without bacteria was used to determine the background of this assay.

\section{Clumping factor and latex agglutination}

All strains of the $S$. lugdunensis collection were tested for agglutination using the commercial $S$. aureus agglutination kit Slidex Staph Plus (bioMérieux). For detection of fibrinogen clumping a single colony of S. lugdunensis was stirred into $50 \mu \mathrm{l}$ of human citrate plasma and then placed onto a glass slide. An agglutination within $60 \mathrm{~s}$ was interpreted as a positive result (Table 2). The $S$. aureus Newman (ATCC 25904) was used as a positive control.

\section{Hemolysis on Columbia blood agar plates}

Bacteria were plated from the frozen stock cultures onto Columbia blood agar plates with $5 \%$ sheep blood (bioMérieux) and were grown for $24 \mathrm{~h}$ and $48 \mathrm{~h}$ of incubation at $37^{\circ} \mathrm{C}$. In order to characterize the grade of the betahemolysis induced by S. lugdunensis, the distinct hemolysis was compared to that of an S. carnosus TM 300 and S. aureus Cowan I. Strains with a complete hemolysis after $24 \mathrm{~h}$ of incubation were interpreted as positive compared to the negative control S. carnosus TM 300 (ATCC 51365). Strains with a hemolysis after $48 \mathrm{~h}$ of incubation similar to that of S. aureus Cowan I (ATCC 12598) were interpreted as producing strong hemolysis.

\section{Results and Discussion}

For S. aureus identification, agglutination-based kits are often used. These kits usually include antibodies against fibrinogen binding proteins. It has been described that some strains of S. lugdunensis react in these agglutination tests [20]. The correct identification of S. lugdunensis is thus difficult. For the identification of $S$. lugdunensis the determination of PYR and ODC has been described to be sufficient to distinguish $S$. lugdunensis from other Staphylococci $[1,20]$. Moreover, a new species, Staphylococcus pseudolugdunensis, has been recently described, which was also PYR and ODC positive [21]. In addition, PYR negative isolates of $S$. lugdunensis exist. Isolate Stlu 7 (Table 2) was PYR negative and ODC positive. The identification was confirmed by MALDI-TOF MS [15], by sequencing of the sodA gene [17], and also by the detection of the species specific $f b l$ and $\tan A$ genes as previously described. In two other isolates the PYR test was indeterminate (Table 2). Since only $94.8 \%$ of S. lugdunensis isolates were PYR positive, an identification strategy based solely on the determination of the PYR activity could miss an estimated $5 \%$ of the $S$. lugdunensis isolates. In addition, the fibrinogen binding gene $f b l$ has been used to establish a $S$. lugdunensis species-specific PCR [22,23]. In our strain collection all 58 strains were shown to be $f b l$ positive using a primer set targeting the A-region of the $f b l$ gene. This prevalence is similar to the high occurrence of the $f b l$ previously described $[22,23]$. All S. lugdunensis strains were $\tan A$ positive $(100 \%)$ and all were identified as $S$. lugdunensis by MALDI-TOF MS (100\%). Our data suggest using MALDI-TOF MS technology or detection of the $f b l$ or $\tan A$ gene for the identification of $S$. lugdunensis and argues against PYR testing for S. lugdunensis identification.

\section{Fibrinogen binding}

Fibrinogen binding ability is usually targeted in S. aureus identification assays such as the Slidex Staph plus (bioMérieux) and the clumping factor test. It has been previously described that some strains of S. lugdunensis could be misidentified as $S$. aureus using these tests [20]. In our strains, 17 out of 58 (29.3\%) were positive in the clumping factor test and 17 out of 58 (29.3\%) strains were also positive in the $S$. aureus identification kit Slidex Staph plus. Expectedly, all of the strains that reacted in the clumping factor bound to solid phase fibrinogen, too. One isolate (Stlu 20) reacted in the Slidex Staph plus test but did not bind to soluble and solid phase fibrinogen. In another isolate (Stlu 1), binding to soluble and solid phase fibrinogen was detected but no agglutination was observed in the Slidex Staph plus test (Table 2). It has been recently reported that S. aureus 
virulence in sepsis is facilitated by the multiple repeats within an fibrinogen and fibronectin binding adhesin [24]. In the subgroup of blood culture samples $43.7 \%$ of the strains bound to fibrinogen compared to $26.5 \%$ in the subgroup of wound swabs. Nevertheless, the difference was statistically not significant as tested by Fischer's exact test. Differences in fibrinogen binding may be explained by different expression of the fibrinogen binding proteins. Moreover, the production of an extra cellular matrix, such as a capsule, which has been described for S. lugdunensis [2] could also mask the accession of an adhesin. Similar results has been described for S. aureus: fibrinogen binding greatly varies within the strains [25]. In contrast to previous reports, where $64.7 \%$ [26] and $83.7 \%$ [27] had been described as clumping factor positive $29.3 \%$ of our strains would be misidentified as $S$. aureus in the clumping factor and in the Slidex Staph plus agglutination test. In all strains, the genes for the FbpA-homologue (SLGD_01696) and $f b l$ were present and, therefore we cannot judge if FbpA is involved in fibrinogen binding. Whether $f b l$ or other fibrinogen binding proteins react in these assays warrants confirmation in future studies. The occurrence of the $v w b l$ gene was also high (98.2\%), similar to a previous report [18].

No statistical difference was observed in our study with regard to the type of clinical specimen from which the isolate was obtained and the fibrinogen binding phenotype. A cluster analysis was performed, but also did not show any correlation of bacterial phenotype and sample source (data not shown).

\section{Beta-hemolysis}

The ability to induce beta-hemolysis on Columbia blood agar plates (bioMérieux) after $24 \mathrm{~h}$ incubation and $48 \mathrm{~h}$ incubation was investigated. The beta-hemolysis of most strains of S. lugdunensis was weaker compared to S. aureus. Only a hemolysin similar to delta hemolysin of $S$. aureus has been described for S. lugdunensis [28]. In addition, synergistic hemolysins have also been described $[11,12,29]$. Similar to findings by others, virtually all strains showed hemolysis after $48 \mathrm{~h}$ of incubation [30]. The hemolysis of red blood cells is an important pathogenicity factor. Expectedly, the iron level is an important regulator for hemolysin expression in many bacteria such as Serratia marcescence [31] and E. coli [32]. Fifty-four of 58 strains (93.1\%) showed no hemolysis after $24 \mathrm{~h}$. After $48 \mathrm{~h}$ three strains also showed no hemolysis, two strains showed a weak hemolysis, 49 showed distinct hemolysis and four showed a strong hemolysis, similar to the hemolysis induced by $S$. aureus after $48 \mathrm{~h}$. In all strains the gene for hemolysin III was found. Fifty-six out of 58 strains were also positive for the beta-hemolysin gene. Interestingly, 30 out of
58 strains (only 51.7\%) were negative for the PCR detecting the SLUSH gene cluster. The initially described [11] SLUSH gene cluster (SLUSH A to C) was annotated as methylated-DNA protein-cysteine methyltransferase (SLGD_00440), and has an identity of $89 \%$ in the newly sequenced S. lugdunensis genome [13]. The gene SLGD_00441 was annotated as SLUSH B with an identity of $92 \%$ to the previously described gene cluster [11]. The following gene SLGD_00442 was also annotated as "SLUSH B" with an identity of $87 \%$ to the previously described gene cluster [11]. Interestingly, three out of four strains that were strongly positive with regard to phenotypic hemolysis were negative in the SLUSH gene specific PCR (Table 2). Notably, SLUSH gene-derived proteins have also been described as phenol soluble modulins [33]. This indicates that the SLUSH gene locus could be different or non-prevalent in an approximately $50 \%$ of the strains and therefore the SLUSH gene cluster and the basis of hemolysis should be characterized in further detail. No statistical difference was observed in our study with regard to the type of clinical specimen from which the isolate was obtained and the hemolysis phenotype.

\section{Conclusion}

In this study we described a PYR negative isolate of $S$. lugdunensis. Our data indicate that a matrix-assisted laser desorption ionisation time-of-flight MS-based identification of S. lugdunensis or species-specific PCR's, detecting the $f b l$ or the $\tan A$ gene, should be used in favour of a PYR testing. In addition, this study provides a first look into the occurrence of putative fibrinogen-binding proteins and suspected hemolysins of S. lugdunensis and their phenotypic correlates. The $f b l$, the FbpA-homologue (SLGD 1696) and the $v w b l$ are highly prevalent in S. lugdunensis strains. Notably, this high occurrence was independent of the fibrinogen binding ability of the strains. In contrast to previous reports only $29.3 \%$ of the strains bound to fibrinogen. Such strains could be misidentified as $S$. aureus in fibrinogen binding-based agglutination tests. Genes coding for hemolysins (hemolysin III [SLGD_00847] and beta-hemolysin [SLGD_00006]) are also highly prevalent in the strains except for the SLUSH gene cluster, which was detected in only an approximately $50 \%$ of the strains. This indicates that the SLUSH gene locus could be different or non-prevalent among many strains. The fibrinogen binding and hemolysis phenotypes were independent of the type of clinical specimen from which the isolates were obtained.

\section{Acknowledgements}

We thank Cindy Richter (Bochum, Germany) for excellent MALDI-TOF MS species identification and Gurpreet Khaira (Vancouver, Canada) for critically reading the manuscript. 
This study was funded in part by a FORUM (Bochum University local funding) grant.

\section{Authors' contributions}

FS conceived and coordinated this study in addition to drafting the manuscript. YN, LM, SN and MiK carried out the molecular characterization and agglutination tests. FS, MaK and SG edited the manuscript. All authors read and approved the final manuscript.

\section{Competing interests}

The authors declare that they have no competing interests.

Received: 26 October 2010 Accepted: 8 April 2011

Published: 8 April 2011

\section{References}

1. Patel R, Piper KE, Rouse MS, Uhl JR, Cockerill FR, Steckelberg JM: Frequency of isolation of Staphylococcus lugdunensis among staphylococcal isolates causing endocarditis: a 20-year experience. J Clin Microbiol 2000, 38:4262-4263.

2. Frank KL, Del Pozo JL, Patel R: From clinical microbiology to infection pathogenesis: how daring to be different works for Staphylococcus lugdunensis. Clin Microbiol Rev 2008, 21:111-133.

3. Hellbacher C, Tornqvist E, Soderquist B: Staphylococcus lugdunensis: clinical spectrum, antibiotic susceptibility, and phenotypic and genotypic patterns of 39 isolates. Clin Microbiol Infect 2006, 12:43-49.

4. Pareja J, Gupta K, Koziel H: The toxic shock syndrome and Staphylococcus lugdunensis bacteremia. Ann Intern Med 1998, 128:603-604.

5. Vandenesch F, Etienne J, Reverdy ME, Eykyn SJ: Endocarditis due to Staphylococcus lugdunensis: report of 11 cases and review. Clin Infect Dis 1993, 17:871-876.

6. Que YA, Haefliger JA, Piroth L, Francois P, Widmer E, Entenza JM, Sinha B, Herrmann M, Francioli P, Vaudaux P, Moreillon P: Fibrinogen and fibronectin binding cooperate for valve infection and invasion in Staphylococcus aureus experimental endocarditis. J Exp Med 2005, 201:1627-1635.

7. Piroth L, Que YA, Widmer E, Panchaud A, Piu S, Entenza JM, Moreillon P: The fibrinogen- and fibronectin-binding domains of Staphylococcus aureus fibronectin-binding protein A synergistically promote endothelial invasion and experimental endocarditis. Infect Immun 2008, 76:3824-3831.

8. Mitchell J, Tristan A, Foster TJ: Characterization of the fibrinogen-binding surface protein Fbl of Staphylococcus lugdunensis. Microbiology 2004, 150:3831-3841

9. Nilsson M, Bjerketorp J, Guss B, Frykberg L: A fibrinogen-binding protein of Staphylococcus lugdunensis. FEMS Microbiol Lett 2004, 241:87-93.

10. Geoghegan JA, Ganesh VK, Smeds E, Liang X, Hook M, Foster TJ: Molecular characterization of the interaction of staphylococcal microbial surface components recognizing adhesive matrix molecules (MSCRAMM) CIfA and Fbl with fibrinogen. J Biol Chem 2010, 285:6208-6216.

11. Donvito B, Etienne J, Denoroy L, Greenland T, Benito Y, Vandenesch F: Synergistic hemolytic activity of Staphylococcus lugdunensis is mediated by three peptides encoded by a non-agr genetic locus. Infect Immun 1997, 65:95-100

12. Donvito B, Etienne J, Greenland T, Mouren C, Delorme V, Vandenesch F: Distribution of the synergistic haemolysin genes hld and slush with respect to agr in human staphylococci. FEMS Microbiol Lett 1997, 151:139-144.

13. Tse H, Tsoi HW, Leung SP, Lau SK, Woo PC, Yuen KY: Complete genome sequence of Staphylococcus lugdunensis strain HKU09-01. J Bacteriol 2010, 192:1471-1472.

14. Christie J, McNab R, Jenkinson HF: Expression of fibronectin-binding protein FbpA modulates adhesion in Streptococcus gordonii. Microbiology 2002, 148:1615-1625.

15. Szabados F, Woloszyn J, Richter C, Kaase M, Gatermann S: Identification of molecularly defined Staphylococcus aureus strains using matrix-assisted laser desorption/ionization time of flight mass spectrometry and the Biotyper 2.0 database. J Med Microbiol 2010, 59:787-790.

16. Noguchi N, Goto K, Ro T, Narui K, Ko M, Nasu Y, Utsumi K, Takazawa K, Moriyasu F, Sasatsu M: Using the tannase gene to rapidly and simply identify Staphylococcus lugdunensis. Diagn Microbiol Infect Dis 2009, 66:120-123.
17. Poyart C, Quesne G, Boumaila C, Trieu-Cuot P: Rapid and accurate specieslevel identification of coagulase-negative staphylococci by using the sodA gene as a target. J Clin Microbiol 2001, 39:4296-4301.

18. Nilsson M, Bjerketorp J, Wiebensjo A, Ljungh A, Frykberg L, Guss B: A von Willebrand factor-binding protein from Staphylococcus lugdunensis. FEMS Microbiol Lett 2004, 234:155-161.

19. Hartford O, Francois P, VaudauX P, Foster TJ: The dipeptide repeat region of the fibrinogen-binding protein (clumping factor) is required for functional expression of the fibrinogen-binding domain on the Staphylococcus aureus cell surface. Mol Microbiol 1997, 25:1065-1076.

20. Shin JH, Jung HJ, Lee HR, Kim JH, Kim HR, Lee JN: Prevalence, identification, and antimicrobial susceptibility of Staphylococcus lugdunensis from various clinical specimens in Korea. Jpn J Infect Dis 2007, 60:312-313.

21. Tang YW, Han J, McCormac MA, Li H, Stratton CW: Staphylococcus pseudolugdunensis sp. nov., a pyrrolidonyl arylamidase/ornithine decarboxylase-positive bacterium isolated from blood cultures. Diagn Microbiol Infect Dis 2008, 60:351-359.

22. Chatzigeorgiou KS, Siafakas N, Petinaki E, Zerva L: fbl gene as a speciesspecific target for Staphylococcus lugdunensis identification. J Clin Lab Anal 2010, 24:119-122.

23. Pereira EM, Oliveira FL, Schuenck RP, Zoletti GO, Dos Santos KR: Detection of Staphylococcus lugdunensis by a new species-specific PCR based on the $\mathrm{fbl}$ gene. FEMS Immunol Med Microbiol 2010, 58:295-298.

24. Edwards AM, Potts JR, Josefsson E, Massey RC: Staphylococcus aureus host cell invasion and virulence in sepsis is facilitated by the multiple repeats within FnBPA. PLoS Pathog 2010, 6:e1000964.

25. Ythier M, Entenza JM, Bille J, Vandenesch F, Bes M, Moreillon P, Sakwinska O: Natural variability of in vitro adherence to fibrinogen and fibronectin does not correlate with in vivo infectivity of Staphylococcus aureus. Infect Immun 2010, 78:1711-1716.

26. Mateo M, Maestre JR, Aguilar L, Cafini F, Puente P, Sanchez P, Alou L, Gimenez MJ, Prieto J: Genotypic versus phenotypic characterization, with respect to susceptibility and identification, of 17 clinical isolates of Staphylococcus lugdunensis. J Antimicrob Chemother 2005, 56:287-291.

27. Iorio NL, Ferreira RB, Schuenck RP, Malvar KL, Brilhante AP, Nunes AP, Bastos CC, Dos Santos KR: Simplified and reliable scheme for species-level identification of Staphylococcus clinical isolates. J Clin Microbiol 2007, 45:2564-2569.

28. Vandenesch F, Storrs MJ, Poitevin-Later F, Etienne J, Courvalin P, Fleurette J: Delta-like haemolysin produced by Staphylococcus lugdunensis. FEMS Microbiol Lett 1991, 62:65-68.

29. Hebert GA: Hemolysins and other characteristics that help differentiate and biotype Staphylococcus lugdunensis and Staphylococcus schleiferi. J Clin Microbiol 1990, 28:2425-2431.

30. Bocher S, Tonning B, Skov RL, Prag J: Staphylococcus lugdunensis, a common cause of skin and soft tissue infections in the community. $J$ Clin Microbiol 2009, 47:946-950.

31. Poole K, Braun V: Iron regulation of Serratia marcescens hemolysin gene expression. Infect Immun 1988, 56:2967-2971.

32. Grunig HM, Rutschi D, Schoch C, Lebek G: The chromosomal fur gene regulates the extracellular haemolytic activity encoded by certain hly plasmids. Zentralbl Bakteriol Mikrobiol Hyg A 1987, 266:231-238.

33. Rautenberg M, Joo HS, Otto M, Peschel A: Neutrophil responses to staphylococcal pathogens and commensals via the formyl peptide receptor 2 relates to phenol-soluble modulin release and virulence. FASEB J 2011 Apr 25, , 4: 1254-1263.

doi:10.1186/1756-0500-4-113

Cite this article as: Szabados et al:: Occurrence of genes of putative fibrinogen binding proteins and hemolysins, as well as of their phenotypic correlates in isolates of S. lugdunensis of different origins. BMC Research Notes 2011 4:113. 